KS. ZDZISŁAW KROPIDŁOWSKI* - BYDGOSZCZ-GDAŃSK

\title{
DZIALALNOŚĆ GOSPODARCZA KS. FRANCISZKA JÓZEFA WYBICKIEGO (1709-1765)
}

Ks. Franciszek Józef Wybicki (1709-1765) pochodził ze znanej rodziny pomorskiej, z której wywodziło się kilku urzędników państwowych. Szczególnie znany jest Józef Wybicki (1747-18220, twórca hymnu narodowego ${ }^{1}$ oraz ks. Joachim Wybicki (1747-1807), mianowany 7 grudnia 1779 roku na prepozyta parafii skarszewskiej². Wszyscy pieczętowali się herbem Rogala ${ }^{3}$.

Ks. Franciszek Józef Wybicki urodził się w 1709 roku w archidiakonacie malborskim diecezji pomezańskiej. Jego ojciec, Piotr, był sędzią ziemskim mirachowskim, a matka, Konstancja z Lniskich - córką sędziego ziemskiego mirachowskiego Jana Lniskiego, właściciela Brodnicy i Lubieszyna. Wybiccy posiadali Będomin i Będominek oraz działy w Lubaniu i Mściszewicach; należeli do grupy średniozamożnej szlachty, utrzymywali się głównie z sądownictwa, sprawowaniu różnych funkcji kościelnych i dobrym koligacjom. Piotr Wybicki był stronnikiem króla Stanisława Leszczyńskiego i uczestniczył w obronie Gdańska przed wojskami rosyjskimi i saskimi ${ }^{4}$. Nie wiadomo kiedy Józef Franciszek został kapłanem i w którym seminarium studiował. Jego historia zaczyna się 22 listopada 1736 roku, kiedy to został prepozytem w Skarszewach.

O swojej działalności gospodarczej, a nieco mniej duszpasterskiej, napisał w oświadczeniu złożonym w konsystorzu gdańskim, wciagniętym do akt 29 sierpnia 1758 roku. Jest to relacja z trwającego 22 lata zwierzchnictwa nad parafią,

* Ks. Zdzisław Kropidłowski - dr hab. historii; prof. Uniwersytetu Kazimierza Wielkiego w Bydgoszczy (Katedra Informacji Naukowej i Bibliologii).

${ }^{1}$ W. Zajewski, Wybicki Józef, w: Stownik Biograficzny Pomorza Nadwiślańskiego, t. 4, Gdańsk 1997, s. 493-496.

${ }^{2}$ T. Nowicki, Stownik biograficzny rzq̨dców parafii archidiakonatu pomorskiego $w$ XVIII wie$k u$, Lublin 2003, s. 232.

${ }^{3}$ J. Krzepela, Rody ziem pruskich, Kraków 1927, s. 1.

${ }^{4}$ M. Dzięcieleski, Dzieje ziemi mirachowskiej od XII do XVIII wieku, Gdańsk 2000, s. 194, przyp. 60.

${ }^{5}$ Archiwum Diecezji Chełmińskiej [dalej ADCh], sygn. G-60, s. 77-87. 
sporządzona prawdopodobnie z konieczności zabezpieczenia archiwaliów przed klęskami żywiołowymi, takimi jak na początku XVIII w., kiedy pożar pochłonął miasto, kościół i zabudowania parafialne wraz z archiwum ${ }^{6}$.

Innym powodem opracowania tego zestawienia mogła być chęć wykazania, jak bardzo powiększył dobra wchodzące w skład powierzonego mu beneficjum przy zabieganiu o biskupią zgodę na zatwierdzenie testamentu prepozyta. Mówią o tym uchwały synodu prowincjonalnego gnieźnieńskiego z czasów abpa Stanisława Szembeka z 1720 roku (wydane drukiem w Warszawie) ${ }^{7}$ oraz synodu diecezjalnego poznańskiego z 1738 roku$^{8}$. Presja tych uchwał musiała być duża, gdyż Wybicki zastosował się do nich również w swoim testamencie.

Prawdopodobnie posiadał on wykształcenie teologiczno-prawnicze, ponieważ przez długi czas pełnił funkcję surogata kilku oficjałów gdańskich (w latach 1743-1765). Pierwszy na swojego surogata powołał go oficjał Piotr Sikorski ${ }^{9}$, który sprawował tę funkcję dwukrotnie w latach $1743-1751$ i 1758-1761 ${ }^{10}$. Ks. F. J. Wybicki surogatem był także za oficjała Józefa Iwańskiego w latach 1751-1758, Piotra Sikorskiego w latach 1758-1761, Cypriana Wolickiego w latach 17611765. Już w 1747 roku był notowany jako kanonik katedralny włocławski, a w 1764 roku został archidiakonem pomorskim. Zarówno funkcje duszpasterskie w parafii, jak i urzędy diecezjalne surogata i archidiakona sprawował do śmierci w dniu 16 kwietnia 1765 roku $^{11}$. Dnia 29 kwietnia 1758 roku papież Benedykt XIV mianował go kanclerzem kościoła kolegiackiego w Kruszwicy. Akt nominacji ustala dla niego dochody ,nie przekraczające 24 dukatów złota ze skarbca” świątyni ${ }^{12}$. Kumulowanie kanonii i nierezydencja w parafii z powodu nadmiaru obowiązków diecezjalnych były w tym czasie regułą ${ }^{13}$.

Ks. F. J. Wybickiemu bardzo zależało na wykazaniu swoich osiagnięć w pracy organizacyjnej, co miało świadczyć o całkowitym oddaniu dla Kościoła i o jego głębokiej wierze. Świadczy o tym umieszczenie w aktach konsytorza gdańskiego trzech dokumentów. Pierwszy to odpis papieskiej nominacji na kanclerza kapituły kolegiackiej przy kościele w Kruszwicy. (Oryginalny indult odebrał bp Antoni Sebastian Dembowski, a autentyczność jego zbadał Piotr Paweł Sikorski, wikariusz generalny biskupa włocławskiego i pomorskiego, i dostarczył do oficjała generalnego gdańskiego, jako przełożonego nominata oraz prałatów i kanoników kościoła kolegiackiego kruszwickiego) ${ }^{14}$. W dokumencie tym, datowanym 29 kwietnia 1758 roku, Benedykt XIV mianował ks. F. J. Wybickiego kanclerzem

\footnotetext{
${ }^{6}$ ADCh, sygn. G-56, s. 51.

${ }^{7}$ Constituciones Synodi Archidioecesis Gnesnensis... Stanislao Szembek... A.D. 1720, Varsoviae [b.r.w.].

${ }^{8}$ Synodus diaecesana Posnaniensis... Stanislao Hosio A. D. 1738, [b.r. i m.w.].

${ }^{9}$ Nowicki, Stownik biograficzny, s. 232.

${ }^{10}$ Tamże, s. 201.

${ }^{11}$ Tamże, s. 232.

${ }^{12}$ ADCh, G-60, s. 8-10.

${ }^{13}$ S. Litak, Parafie w Rzeczypospolitej w XVI-XVIII wieku. Struktura, funkcje spoteczno-religijne i edukacyjne, Lublin 2004 ,s. 152-153.

${ }^{14}$ ADCh, sygn. G-60, s. 8-13.
} 
kapituły kruszwickiej i oddalił roszczenia innych osób do tej godności, nakazał złożyć przysięgę na wierne sprawowanie powierzonej mu funkcji i zezwolił na powołanie wikariusza, który by w razie potrzeby zastępował go w pracy duszpasterskiej lub w kancelarii kolegiackiej. Z okazji tego zapisu odnotowano, że ks. F. J. Wybicki odbudował spalony w 1712 roku kościół skarszewski pw. św. Michała Archanioła, który konsekrował 10 czerwca 1750 roku bp sufragan Fabian Franciszek Pląskowski i nadał wiernym za przybycie na tę uroczystość odpust 1 roku, a za nawiedzanie kościoła w jej rocznicę, 40 dni. Przywilej ten został potwierdzony i wpisany do ksiag parafialnych 10 czerwca 1758 roku na plebanii w Skarszewach w czasie następnej wizyty bpa w tym mieście. Ks. F. J. Wybicki ufundował również 2 ołtarze, główny ku czci św. Michała Archanioła i drugi poświęcony Najświętszej Marii Pannie ${ }^{15}$.

Innym dokumentem jest sprawozdanie z zarządzania parafią przez 22 lata, od 1736 do 1758 roku. Zarządzał on w tym czasie nie tylko beneficjum, ale również dobrami należącymi do kościoła parafialnego, z których dochody powinny płynąć do kasy kościelnej na utrzymanie i sprawowanie kultu.

Ks. F. J. Wybicki podał, że kościół parafialny posiada 1 łan gruntów ornych, które otrzymał w 1642 roku. Nie wymienił jednak fundatora, ale zaznaczył, że grunty te zostały przekazane prepozytom w użytkowanie, aby z osiagniętych dochodów wpłacali do kasy kościoła 6 florenów rocznie ${ }^{16}$. Natomiast według relacji powizytacyjnej archidiakona Konstantego Szaniawskiego z 1711 roku $^{17}$ i Augustyna Kilińskiego z 1750 roku wynika, że posiadał on 2 łany ${ }^{18}$. Wszyscy zgodnie mówią o tym, że do Kościoła należały również 3 kawałki pól, tzw. Hapsztuki. Za czasu Wybickiego były one zasiedlone przez 3 rodziny, a na ich powierzchnię składały się m. in. ogrody i łąki. Pierwsze pole zostało zapisane Kościołowi 21 listopada 1627 roku. Darowiznę tę wciągnięto do akt sądu grockiego w 1642 roku. Drugi został odnotowany $\mathrm{w}$ tymże sądzie w poniedziałek po niedzieli Cantate w 1692 roku, a trzeci na podstawie aktu odręcznego sporządzonego na probostwie 16 lipca 1733 roku przez Mateusza Laskowskiego, który uczynił to we własnym imieniu i w imieniu swoich następców.

Ks. F. J. Wybicki uważał, że pola te powinien uprawiać każdy prepozyt skarszewski razem z ziemią beneficjalną, bo tak nakazywał dawniej archidiakon Jan Kazimierz Jugowski, ale obowiązkiem prepozytów jest płacić kościołowi rocznie 9 florenów. Podkreślił, że od momentu objęcia parafii tak czynił, teraz ,zobowiązuje, prosi i zaklina” swoich następców, aby nie „ośmielali się ograbiać” kościoła $\mathrm{z}$ tego dochodu ${ }^{19}$.

Nadto uważał, że każdy prepozyt powinien pamiętać o przekazywaniu na rzecz świątyni 6 florenów rocznie, jako procentu od kwoty 100 florenów, ofiarowanych przez mieszczanina skarszewskiego Pawła Pett w 1643 roku, którymi obracali każdorazowi burmistrze miasta. W tym czasie był to Jerzy Flaxhar.

\footnotetext{
${ }^{15}$ Tamże, s. 13.

${ }^{16}$ ADCh, sygn. G-60, s. 77.

${ }^{17}$ ADCh, sygn. G-26, s. 176

${ }^{18}$ ADCh, sygn. G-56, s. 52.

${ }^{19}$ ADCh, sygn. G-60, s. 78.
} 
Dochody kościoła najbardziej pomnażały czynsze z 3 domów na parcel położonych w pobliżu kościoła, z których płacili razem 30 florenów rocznie, czyli po 10 florenów od domu. Kwotę tę mieli uiszczać na św. Marcina, by prepozyci przeznaczali je na utrzymanie płomienia w wiecznej lampce przed Najświętszym Sakramentem ${ }^{20}$. Razem dochody kościoła parafialnego wynosiły 51 florenów rocznie, które według F. J. Wybickiego dawniej były przejmowane przez różne osoby. Nic nie wspomniał o dochodach wpływających z taksy za iura stolae, według której świątyni należał się jeden floren za miejsce na cmentarzu ${ }^{21}$. Zapewne zwyczaj ten dawniej był przestrzegany i dlatego nie został przez niego wymieniony.

Tabela 1. Dochody świątyni w latach 1758-1766

\begin{tabular}{|c|l|l|l|l|}
\hline L.p. & Dzierżawa gruntów & Dzierżawa zabudowań & Legat & Taksa za pogrzeby \\
\hline 1 & Łan za 6 florenów & & & \\
\hline 2 & $\begin{array}{l}3 \text { grunty Hapsztuki za } \\
\text { 9 florenów }\end{array}$ & & & \\
\hline 3 & & 3 domy za 30 florenów & & $\begin{array}{l}\text { 6 florenów z legatu 100 } \\
\text { florenów }\end{array}$ \\
\hline 4 & & & & $\begin{array}{l}\text { miejsca na cmentarzu } \\
\text { dla ok. 50 zmarłych za } \\
50 \text { florenów }\end{array}$ \\
\hline 5 & & & & \\
\hline Razem & 101 florenów & & \multicolumn{3}{|l}{} \\
\hline
\end{tabular}

Znacznie więcej miejsca poświęcił Wysocki własnym dokonaniom dotyczącym beneficjum. „Zaprawdę, ponieważ w czasie trwania mojego zwierzchnictwa przez 22 lata, powiększyły się niektóre przychody, a beneficjum to doprowadziłem do lepszego i doskonalszego stanu, gdy sprzyjały temu niebiosa, stosownie do powinności mojego urzędu, pozostawiam[...] następcom pamiątkę wszystkich i poszczególnych dochodów, odnoszących się do kościoła i prepozytury"22.

Uposażenie kleru parafialnego od średniowiecza nie uległo zasadniczo zmianom. Jego podstawą był system beneficjalny. Na beneficjum plebańskie zazwyczaj składały się grunty orne, łąki, ogrody, place w miastach, dziesięciny składane w ziarnie i pieniądzu, opłaty z kolędy pobieranej w pieniądzu, z mesznego (missales) za celebrowanie Mszy św. uiszczanego od łanu na św. Marcina w zbożu i pieniądzu oraz stołowego (mensalia), pobieranego w miastach od ludności bezrolnej i małorolnej na Wielkanoc.

S. Litak i E. Wiśniowskim uważają, że meszne i powiązane z nim stołowe płaciła ludność zamieszkała na południowo-zachodnich i zachodnich terenach

${ }^{20}$ Tamże.

${ }^{21}$ Z. Kropidłowski, Taksa za posługi duszpasterskie $w$ archidiakonacie pomorskim $w$ XVII-XVIII w., ,Studia Gdańskie”, 15-16 (2002-2003) s. 67.

${ }^{22}$ ADCh, sygn. G-60, s. 77: Verum quoniam stante mea possessione per annos viginti duos, nonnulli redditus aucti, ac beneficium hoc ad meliorem et perfectiorem statum faventibus superis cum reduxerim, pro debito Officii mei, relinquo gratis utinam labarum meorum Successoribus memoriale universorum et singulorum proventuum Ecclesiae et Praepositura. 
Polski, gdzie organizacja Kościoła pozostawała pod wpływem prawa niemieckiego $^{23}$. Dodają, że na beneficjum składały się jeszcze karczmy z prawem do propinacji, młyny, sadzawki rybne i jazy, kapitały złożone na procent w kahałach żydowskich lub na dobrach ziemskich, rozmaite zezwolenia na łowienie ryb w rzekach albo stawach. Do tego dochodził wolny przemiał zboża na własne potrzeby w młynach, wolny wyrąb drzewa w lasach i wolny wypas trzody w dobrach różnych właścicieli. Podaje, że w niektórych miastach i wsiach pobierano opłaty od Żydów, a w skupiskach protestantów również i od nich. Przyznaje, że ważnym źródłem dochodów były również trudne do ustalenia ofiary za posługi religijne, czyli iura stolae, a także z tacy i jałmużny. Za najważniejsze źródło dochodów uznaje dziesięciny, które były jednak nieregularnie wypłacane, co powodowało długotrwałe procesy duchowieństwa $\mathrm{z}$ dłużnikami. Podobnie jak Waldemar Kowalski $^{24}$ i Dariusz Główka ${ }^{25}$ za drugorzędne źródła dochodów uważa gospodarstwa plebańskie ${ }^{26}$. Podaje przeciętną wielkość gospodarstwa plebańskiego, która wynosiła w zachodniej Wielkopolsce i ziemi chełmińskiej w XVII w. 1,6 łana, w archidiecezji gnieźnieńskiej 2-4 włók, w diecezji płockiej 2,7 włóki, a w archidiakonacie pomorskim $3,5^{27}$.

$\mathrm{Na}$ beneficjum skarszewskie składało się przede wszystkim 6 łanów gruntów rolnych. Była to powierzchnia większa niż przeciętna w parafiach archidiakonatu pomorskiego $^{28}$. Zapis jednak jest niejednoznaczny. Ks. F. J. Wybicki pisze, że do areału ustanowionego na mocy dokumentu erekcji parafii dołączono z czasem 4 łany i odłączono 2 łany. Ostatecznie w 1758 roku było ich 6 . Można by z tego wnosić, że beneficjum początkowo wynosiło 4 łany, jednak joannici - fundatorzy miasta - wytyczyli dla proboszczów 6 łanów i rozległe tereny leśne ${ }^{29}$. O tych drugich prepozyt niewiele wspomina. Główny obszar beneficjum był wydzielony wyraźnymi znakami granicznymi, którymi były kamienie z wyrytym krzyżem, wyróżniające się w terenie, bo wkopane w kopce ziemi. Obszar ten graniczył m. in. z dobrami klasztoru pelplińskiego, położonymi we wsi Więckowy. Wybicki uważał, że część gruntów plebańskich przywłaszczyli sobie jakiś czas temu jej mieszkańcy, dlatego od kilku lat toczył proces graniczny z cystersami pelplińskimi. Przed objęciem placówki przez ks. F. J. Wybickiego, dzierżawcy za wynajem głównego folwarku beneficjalnego, płacili duchownym 150 florenów rocznie. On

${ }^{23}$ Litak, Parafie w Rzeczypospolitej w XVI-XVIII wieku, s. 138; E. Wisniowski, Kolęda-meszne - stołowe na ziemiach polskich. Problem rejonizacji, w: Kultura średniowieczna i staropolska, Warszawa 1991, s. 625-638.

${ }^{24} \mathrm{~W}$. Kowalski, Uposażenie parafii archidiakonatu sandomierskiego $w$ XV-XVIII w., Kielce 1998, s. 96

${ }^{25}$ D. Główka, Gospodarka w dobrach plebańskich na Mazowszu w XV-XVIII wieku, Warszawa 1991, s. 77-79

${ }^{26}$ Litak, Parafie w Rzeczypospolitej w XVI-XVIII wieku, s. 139-140.

${ }^{27}$ Tamże, s. 140.

${ }^{28}$ Parafie macierzyste dekanatu puckiego miały najczęściej po 6 włók gruntów ornych. Z. Kropidłowski, Dobra materialne, wyposażenie i dochody parafii, duchowieństwa i stużby kościelnej dekanatu puckiegow okresie staropolskim, Gdańsk 2007, s. 220, tabela 18.

${ }^{29}$ ADCh, sygn. G-59, s. 133. 
pisze o sobie: „,po przywołaniu Boskiej pomocy, wybudowałem od fundamentów nowy folwark ze stodołami, stajniami i nowymi budynkami folwarcznymi i gospodarczymi, poprowadziłem rowy na łąkach i zatroszczyłem się, żeby wykorzystano zarośla i inne rzeczy konieczne do dobrego zarząadzania wprowadziłem i teraz otrzymuję 300 florenów dzierżawy i sześć korców owsa"30.

Oprócz tych dóbr wymienia mały folwark, dawno wzniesiony, „na gruntach należących do prepozytury, co do którego także postarałem się, aby od fundamentów nowy został wzniesiony ze stodołą i innymi budynkami”, ponieważ stary popadł $\mathrm{w}$ ruinę, nie nadawał się do remontu. $\mathrm{Z}$ tego folwarku dzierżawca płacił mu 60 florenów i 6 korców owsa rocznie. Temu dzierżawcy powierzył opiekę nad lasem położonym nieopodal, przy drodze do wsi Junkrowy, pod wzgórzem nazywanym Iafferberg ${ }^{31}$. Las ten został przez prepozyta Jana Lewińskiego, który był duszpasterzem skarzewskim w latach 1712-1730 $0^{32}$, całkowicie spustoszony. Zapewne miało to związek z odbudową świątyni i zabudowań plebańskich po pożarze miasta w 1712 roku. Wybicki natomiast nie pozwalał, ,żeby chociaż mały krzak był wycinany. W następnych latach zadbałem, aby obcinano gałęzie[...] pozwalałem, aby to dzieło moich rąk rosło, a nawet kupuję drewno na użytek domowy z pobliskich lasów, z serca pragnąc pozostawić tego rodzaju beneficjum w jak najlepszym stanie. Dlatego też następcę proszę i zobowiązuję, aby ten las jak ogród założony zachował w każdy możliwy sposób" "33.

Następnie podaje, że prepozytura posiada kilka łąk położonych w różnych miejscach, z których wymienia łąkę położoną nad rzeką Wietcisa w pobliżu wspomnianego lasu, dwie łąki po obu stronach rzeki na miejscu starego zamku oraz łąkę włączoną do dóbr kościelnych na mocy darowizny Ludwika Owidzkiego, asesora sądu ziemskiego tczewskiego i dziedzica dóbr Pawłowo, zapisanej w poniedziałek po wspomnieniu św. Stanisława Biskupa (po 8 maja) 1741 roku. Wymienił jeszcze sześć małych kawałków pól położonych między gruntami rolników, zwanych Przeczki ${ }^{34}$.

${ }^{30}$ Tamże, sygn. G-60, s. 79: Ego vero invocato Dei auxilio e fundamentis novum praedium cum horreis, stabulis, ac aliis aedificiis praedialibus et villanis aedificavi, fossas in pratis duci, ac virgulta eradicari curavi, aliaque ad bonam oeconomiam reduxi et nunc percipio florenos tercentos arendae et sex coretos avenae.

${ }^{31}$ Por. tamże: Ego vero invocato Dei auxilio e fundamentis novum praedium cum horreis, stabulis, ac aliis aedificiis praedialibus et villanis aedificavi, fossas in pratis duci, ac virgulta eradicari curavi, aliaque ad bonam oeconomiam reduxi et nunc percipio florenos tercentos arendae et sex coretos avenae.

${ }^{32}$ Nowicki, Stownik biograficzny, s. 124.

${ }^{33} \mathrm{ADCh}$, sygn. G-60, s. 79: postquam vero ego beneficium hoc obtinuerim, protinus a principio possessionis meae parva quamvis virgulta exsecanda impedivi, sequentibus annis frondes amputari curavi, sub custodiam eiusdem praedioli arendatori tradidi, et excreverunt arbores non exiguae; quod opus manuum mearum crescere sino, et licet pro usu domestico ex sylvis vicinioribus emo ligno, desiderio desiderans huiusmodi beneficium in quam optimo constituere statu. Quapropter etiam successorem rogo et obligo, ut hanc sylvam tanquam hortum plantatum conservet omni possibili modo.

${ }^{34}$ Tamże, s. 80. 
Na beneficjum składało się również kilka ogrodów. Ks. F. J. Wybicki wymienia pierwszy, położony pod zamkiem, za młynem, drugi z przeciwnej strony muru otaczającego probostwo, trzeci na przedmieściach za rzeka, w pobliżu browaru, czwarty wewnątrz murów miejskich, wśród innych ogrodów mieszczan. Wspomina jeszcze o dwóch innych ogrodach należących w XVIII w. do zamku, o których tradycja mówi, że należały kiedyś do parafii. Zostały one przejęte w czasie „potopu" szwedzkiego, gdy proboszcz zmienił wyznanie. K. F. J. Wybicki odkrył w aktach sądu grodzkiego w Skarszewach, że w 1671 roku oba ogrody nazywane Rozgart i Kompstgart, z dwoma stawami i sadami zostały przyznane prepozyturze. On sam korzysta tylko z prawa połowu ryb w tych dwóch stawach i jeziorach miejskich. Przyznał, że od początku swojego pobytu w Skarszewach nakazał wykonać sieci, zwane klepcz, i kila łódeczek i łowił ryby w lecie i zimie. Spowodowało to niezadowolenie Rady Miasta (,zaczęła rada miasta mówić o tego rodzaju łowieniu rozmaitymi językami”) do momentu, gdy ks. F. J. Wybicki przedstawił jej zapis z lustracji mówiący, że „w jeziorach miejskich ma Prepozyt wolne prawo połowu"35.

Tabela 2. Dochody z beneficjum w 1758 roku

\begin{tabular}{|l|c|c|}
\hline \multicolumn{1}{|c|}{ Rodzaj dóbr } & Dochody dawniej uzyskiwane & Dochody w 1758 roku \\
\hline Folwark główny (6 łanów) & 150 florenów & 300 florenów i 6 korców owsa \\
\hline Folwark mały & - & 60 florenów i 6 korców owsa \\
\hline Ogrody & 4 & 6 \\
\hline Prawo do połowu ryb & - & odnowione \\
\hline
\end{tabular}

W dalszej części wymienił dziesięciny, jakie pobiera. Z treści zapisu można przypuszczać, że miasto i sołectwo skarszewskie wywiązywało się ze swoich obowiązków bez zastrzeżeń i składało rocznie po 77 korców pszenicy i owsa. Ks. F. J. Wybicki uzyskał we Wschowie od króla Augusta III 27 lipca 1752 roku potwierdzenie przywilejów nadanych przez króla Zygmunta I i Władysława IV, odnoszących się do mieszkańców wsi należących do parafii. Oryginał dawnych przywilejów znajdował się w aktach sądu ziemskiego, na zamku w Skarszewach. Potwierdził więc, że wierni mają płacić od łanu po korcu pszenicy i owsa. Mimo to z folwarku Nygut płacono po 10 korców pszenicy i owsa, ale ze wsi kmiecej nic nie płacono. Podobnie $\mathrm{z}$ folwarku w Chamerowie płacono po 10 korców pszenicy i owsa, ale ze wsi nic. Dlatego prepozyt Wybicki zapisał, że powstał spór z parafianami. Zapewne w konsystorzu toczył się w tej sprawie następny proces karny. Wieś Demblin płaciła po 20 korców pszenicy i owsa. Właściciele folwarku w Mirowie płacili po 6 korców pszenicy i owsa, ale sołtys i gburzy nic nie płacili i za-

${ }^{35}$ Tamże, s. 80-81: Ego primo statim possessionis meae Anno comparatis mihi parvis retibus alias Klepcz et aliquot naviculis, tam tempore aestivali, quam hyemali etiam in glacie pro mea sustentatione piscari iussi, et in diem praesentem iubeo pacifice absque ulla civitatis impugnatione. A principio coepit magistratus de eiusmodi piscatione intra se variis loqui linguis, sed postquam ipsi punctum in dicta lustratione mihi communicata expressum de tenore tali: "In lacubus civitatensibus habet Praepositus liberam piscaturam». 
pewne również w ich sprawie toczył proces. Natomiast z folwarku w Bożym Polu składano po 10 korców pszenicy i owsa, sołtys płacił po 2 korce obu zbóż, a dwaj kmiecie po jednym korcu pszenicy i owsa. O Czarnocinie zanotował, że dawniej był to mały folwarczek ,mający drobne rolnictwo”, a składał się głównie z borów i lasów. W połowie XVIII w po wykarczowaniu ich posiadał rozległe pola, ale jego właściciel ciagle płacili tylko po 2 korce pszenicy i owsa. Podobnie z dóbr Pawłowa otrzymywał tylko po 2 miary obu zbóż. Jeszcze gorzej wywiązywały się wsie należące do Gdańska - Pruska Karczma i Nowe Kolonie. Z pierwszej prepozyt otrzymywał tylko 3/4 korca obu zbóż, a o należność z drugiej złożył skargę do konsystorza gdańskiego, który 9 lipca 1755 roku postanowił, że każdy chłop powinien płacić po korcu pszenicy i owsa miary gdańskiej lub ich równowartość w dobrej monecie. Odpis postanowienia został sporządzony w sądzie ziemskim w Skarszewach w dniu 12 września 1755 roku, a później jeszcze w Tczewie ${ }^{36}$. Razem dziesięcina wynosiła do 1755 roku 141,75 korca obu zbóż. Po tym roku powinna była wzrosnąć o ofiary ze wsi Nowa Kolonia.

Prepozyci skarszewscy pełnili także funkcje duszpasterskie w parafii filialnej w Szczodrowie, gdzie beneficjum obejmowało 4 włóki gruntów ornych. Dwa łany były ze sobą połączone, a wszystkie wydzierżawione za 50 florenów rocznie ${ }^{37}$.

Zestawienie to nie zgadza się z relacją lustratora starostwa, z której wynika, że otrzymywał on dziesięciny również ze wsi Nygut po 13,75 korca pszenicy i owsa, ze wsi Boże Pole po 6, a nie po 4 miary obu zbóż i ze Szczodrowa, parafii filialnej, po 12 korców pszenicy i owsa. Różnica więc wynosi po 27, 75 miar obu zbóż. Trudno powiedzieć kto się mylił, różnica wynosi prawie $20 \%$. Wielkość dziesięciny z parafii była przeciętna dla archidiakonatu pomorskiego ${ }^{38}$.

Tabela 3. Wielkość dziesięciny w 1758 roku pszenicy i owsa w korcach

\begin{tabular}{|c|l|c|c|}
\hline L.p. & \multicolumn{1}{|c|}{ Miejscowość } & $\begin{array}{c}\text { Dziesięciny według relacji } \\
\text { ks. F. J. Wybickiego }\end{array}$ & $\begin{array}{c}\text { Dziesięciny według lustracji } \\
\text { starostwa }\end{array}$ \\
\hline 1 & Miasto Skarszewy & 77 & - \\
\hline 2 & Nygut folwark & 10 & 13,75 \\
\hline 3 & Nygut wieś & - & - \\
\hline 4 & Chamerowo folwark & 10 & 20 \\
\hline 5 & Demblin wieś & 20 & - \\
\hline 6 & Mirowo folwark & 6 & 6 \\
\hline 7 & Boże Pole folwark & 10 & - \\
\hline 8 & Boże Pole wieś & 4 & - \\
\hline 9 & Czarnocin folwark & 2 & - \\
\hline 10 & Pawłowo & 0,75 & 12 \\
\hline 11 & Pruska Karczma & $(?)$ & - \\
\hline 12 & Nowe Kolonie & - & Różnica wynosi 27,75 \\
\hline 13 & Szczodrowo & 141,75 & - \\
\hline Razem & & & \\
\hline
\end{tabular}

\footnotetext{
36 Tamże, s. 81-82.

37 Tamże, s. 86.

${ }^{38}$ Kropidłowski, Dobra materialne, wyposażenie i dochody parafi, s. 221.
} 
Zestawienie to nie zgadza się również z relacją wizytatora ks. Bartłomieja Trochowskiego z 1765 roku, który pisze, że do parafii skarszewskiej i filialnej w Szczodrowie należały wsie: Chamerowo, Chamerowskie Piece, Mierowo, Dęblin, Nygut, Zapowiednik, Czarnocin, Czarnowskie Piece, karczma zwana Czystawoda, Watachowo, Cylka, nowe kolonie gdańskie Wilk i Krawusino, Szczodorowo z młynem, Englert, Pawłowo, Pawłówko, Celmerostwo, Nowy Wiec, Świnie Budy, Beł Huta, Sucha Huta, Sztruk Huta, Czasz Huta, Górne Piekło, Olszowe Błoto, Granicznik, Nowa Kolonia starostwa skarzewskiego, Pruskie Karczmy Max i Brumsdorf oraz Nowa Kolonia Gdańska.. W tych wsiach tylko czwarta część stanowili katolicy ${ }^{39}$, pozostali uchylali się do składania dziesięcin.

Następnie ks. F. J. Wybicki opisał dochody, jakie pobiera z racji praw stuły, czyli iura stolae. Zostały one ustalone na podstawie ,przestrzeganego w parafii zwyczaju". To nasuwa przypuszczenie, że był on inny niż w całym archidiakonacie pomorskim, $\mathrm{m}$. in. ofiary $\mathrm{z}$ tego tytułu składano w naturze i gotówce. Zapewne też w naturze pobierał z miejscowości zamieszkałych przez luteranów. $Z$ folwarku w Szczodrowie płacono po 10 korców pszenicy i owsa, ze wsi od każdego łanu po 0,5 korca obu zbóż, czyli razem po 9,5 miar, a z młyna tam pracującego 3 korce pszenicy. Szlachta z Nowego Wieca składała po 9,5 korców pszenicy i owsa, choć za czasów prepozyta Jana Jugowskiego (1693-1712) płaciła po 20,5 korców obu zbóż. Wybicki dowiedział się o tym z lektury spisu dochodów wtedy sporządzonego, ale w 1758 roku różnicy tej nie umiał wyjaśnić. Ze wsi Świnio Budy po 2 korce obu zbóż, z Granicznika Nowej Kolonii po korcu pszenicy i owsa. Mieszkańcy Pieców Chamerowskich i Czarnocińskich po 1,5 korców, czyli po 3 miary pszenicy i owsa. Szlachcic Jan Lubomski z dóbr Zapowiednik i Nowa Kolonia płacił po 2 korce obu zbóż. To właśnie pobieranie opłat z tytułu iura stoae w naturze wyróżnia parafię w Skarszewach od innych archidiakonatu pomorskiego. Razem dochody wynosiły 43 korce pszenicy i 40 korców owsa.

Pozostałe miejscowości płaciły iura stolae w monecie. Wieś Barkuta płaciła 6 florenów i 6 groszy, Górne Piekło 7 florenów i 6 groszy, Czasz Huta 4 floreny i 24 grosze, Elembruk 3 floreny. Razem było to 20 florenów i 36 groszy. Z każdego domu wzniesionego w mieście, w którym żyli innowiercy, otrzymywał na Wielkanoc, z tytułu spowiedzi 5 szelagów nazajutrz po uroczystości św. Michała Archanioła, czyli po odpuście parafialnym.

Ale Wybicki uważał, że prepozytom należą się jeszcze opłaty po 3 grosze od każdego mieszkańca, nawet innego wyznania, i w 1750 roku wystapił do sądu ziemskiego w Skarszewach ze skargą na swoich parafian-heretyków. Uzyskał wyrok skazujący ich na takie opłaty. Oni jednak wnieśli odwołanie do Nuncjatury Apostolskiej w Warszawie, później do biskupa ordynariusza włocławskiego i pomorskiego, a w końcu do Królewskiego Sądu Asesorskiego. Prepozyt uważał jednak, że sąd świecki nie jest prawomocny do rozpatrywania spraw duchownych i nie stawiał się na wezwania w oczekiwaniu ,lepszych i bardziej przychylnych dla rzeczy duchowych czasów. Więc wisi sprawa nierozstrzygnięta, którą jeśli nie będę $\mathrm{w}$ stanie zakończyć $\mathrm{z}$ powodu niespodziewanej śmierci, proszę mojego na-

${ }^{39}$ ADCh, sygn. G-61, s. 266-267. 
stępce, aby nie zaprzestał prowadzenia tej sprawy. Pozostawiam mu w archiwum cały gotowy przewód sądowy i dokumenty dla przeprowadzenia czynności sądowych". Dodał, że ma rację, ponieważ w 1740 roku miasto zapłaciło mu 60 florenów w dobrej monecie jako wyrównanie zaległych opłat $\mathrm{z}$ tego tytułu ${ }^{40}$. Innowiercy musieli składać ofiarę z racji chrztu, wynoszącą 1 floren i 24 grosze, a z okazji zawarcia związku małżeńskiego 2 floreny i 48 groszy. Za pogrzeby pobierał tak jak od katolików różne stawki, zależnie od zamożności rodziny zmarłego. Wysokość tych ofiar nie była zgodna z taksą za posługi duszpasterskie uchwaloną dla archidiakonatu pomorskiego. Ks. F. J. Wybicki upominał następców, aby nie rezygnowali ani z nich, ani z prawa wystawiania świadectw zgonów lub dokumentów wdowieństwa, za które również należały się opłaty w wysokości takiej, jak od katolików ${ }^{41}$.

Trudno choćby szacunkowo ustalić, jakie były dochody Wybickiego z racji ofiar iura stolae. Zakładając, że w 1758 roku udzielił tyle samo sakramentów co w 1766 roku celebrował jego następca, czyli 103 chrzty pobierając za każdy po 1 florenie 24 grosze, otrzymał (licząc 1 floren=60 groszy) 144 floreny i 20 groszy. Za 47 pogrzebów pobrał od 100 do 200 florenów, a za 24 śluby, przynajmniej 86 florenów i 40 groszy. Razem dochód z iura stolae mógł wynosić ok. 330-430. Protestanci musieli składać ofiary prepozytowi, mimo że przyjmowali sakramenty z rąk własnych kaznodziejów. Warto tutaj zauważyć, że ofiary za chrzest dziecka były bardzo wygórowane. W taksie dla Pomorza jest mowa o opłatach 1 grosza, a za chrzest dziecka z nieprawego łoża 19 groszy, chociaż łączyła się z tym wyższa opłata (2 floreny) za wywód kobiety ${ }^{42}$. Należy również dodać, że według taksy najbardziejokazały pogrzebze Msząśw.śpiewnąorazuroczystym konduktemihymnem Salve Regina, kosztował 5 florenów 17 groszy i 5 szylingów, a najtańszy 1 floren 5 groszy ${ }^{43}$.

Opisał również ofiary pobierane z racji kolędy i na Wielkanoc. „Prepozytowi lub jego wikaremu, każdy katolik i luteranin, także kaznodzieja [ewangelicki], płaci stosownie do swej woli 4 floreny" ${ }^{4}$. Chodziło tu zapewne o gospodarza, który w imieniu mieszkańców całego zabudowania to czynił. Nadto jeszcze „słudzy i służebnice pozostający w czeladzi 3 grosze datku" dodawali. Natomiast w Nowych Hutach i Nowych Koloniach według zwyczaju chłopi składali od każdego łanu po jednej czwartej korca owsa, które pobierał starosta i przekazywał wikaremu ${ }^{45}$. O ofiarach Wielkanocnych napisał nieco dalej w jednym zdaniu, że

${ }^{40}$ ADCh, sygn. G-60, s.82-83: expectans utinam meliora et spiritualibus favorabiliora tempora, pendet ergo causa indeciso, quam si praeoccupata morte terminare non valuero, rogo successorem meum, ut non intermittat huiusmodi causa promovere, cui relinquo in archivo totum paratum processum et documenta negotium evincendum.

${ }^{41}$ Tamże.

${ }^{42}$ Kropidłowski, Dobra materialne, wyposażenie i dochody parafii, s. 8.

${ }^{43}$ Kropidłowski, Taksa za postugi duszpasterskie w archidiakonacie pomorskim, s. 68.

${ }^{44}$ ADCh, sygn. G-60, s. 83: Denique tempore strenae visitanti Praeposito seu eius vicario, quivis tam catholicus quam lutheranus pendit pro sua libertate strenam, etiam ipse Praediacantius solvit strenae continua praxi florenos quatuor.

${ }^{45}$ ADCh, sygn. G-60, s. 83. 
„otrzymuje ofiary Wielkanocne, czyli spowiedne, od każdego katolika po 3 grosze. Służący i służące pozostający w czeladzi płacą według dawnego zwyczaju 6 groszy"46. Trudno dokładnie ustalić, ile wynosił dochód z kolędy i na Wielkanoc oraz dlaczego służba miała płacić podwójną opłatę za spowiedne. Również na podstawie zachowanych źródeł nie można ustalić liczby parafian według stanu, ale można przyjąć, że gdyby parafię zamieszkiwało około 1000 wiernych, dochód $\mathrm{z}$ tej ofiary sięgałby nawet 2000 florenów .

W czasie wizytacji w 1765 roku odnotowano, że do sakramentów wielkanocnych przystapiło 898 parafian, i że w parafii mieszkało 407 mężczyzn, 450 kobiet, 219 chłopców i 238 dziewczynek. Zatem było 1314 katolików oraz 1713 luteranów ${ }^{47}$; a więc 3027 osób. Katolicy stanowili 43\% mieszkańców.

Ks. F. J. Wybicki szczycił się również tym, że powołując się na przywileje erekcyjne miasta i parafii żądał od władz miasta wybudowania nowej plebanii. Umowę w tej sprawie zawarł z nimi 7 stycznia 1744 roku. Obejmowała ona również obietnicę wzniesienia także dwóch spichlerzy do przechowywania zboża prepozyta. $Z$ budową tego drugiego miasto zwlekało, ale w 1758 roku był on już wybudowany. Wybicki przypomniał władzom, że ma również prawo propinacji piwa i sprzedawania go w czasie jarmarków. Cech piekarzy upomniał, że zgodnie z dawną umową ma dostarczać każdego roku prepozytowi pieczywo o wartości 25 florenów oraz mąkę pszenną „na wystarczające potrzeby Kościoła”, a na Wielkanoc i Zielone Świątki chleb pszenny „słusznej wielkości”.

Jednak w momencie powołania na urząd ks. F. J. Wybickiego od zwyczajów tych odstapiono. On poznawszy swoje prawa, po roku zawarł z piekarzami nowa umowę, w której zobowiązali się płacić 30 florenów gotówką i dostarczać mąkę oraz chleb na dwa święta. Z porozumienia tego wywiązywali się tylko przez 11 lat, czyli do 1749 roku, kiedy ze względu na trudności gospodarcze poprosili o zwolnienie $\mathrm{z}$ tych opłat i je uzyskali.

Podobne opłaty musieli wnosić rzeźnicy, którzy do chwili objęcia parafii przez Wybickiego płacili rocznie 25 florenów i 3 funty wołowiny przed każdą niedzielą. Także winiarze dawniej dostarczający parafii tyle wina, ile było potrzeba na odprawianie Mszy św., od 1736 roku odstapili od tego zwyczaju. Dlatego postanowił skorzystać ze swoich przywilejów i zorganizował we własnych dobrach wypiek chleba i ubój wołów. Działalność ta musiała być uciążliwa, bo niedługo przed 1758 roku prawo to odstapił karczmarzowi Michałowi Preys, który za możliwość wypiekania chleba, ubój zwierząt i rozlewanie wina płacił rocznie 40 florenów i dostarczał chleb i wino na potrzeby plebanii ${ }^{48}$. Natomiast nie zrezygnował z prawa ważenia piwa i wybudował nad rzeką nowy browar, w którym zatrudniał piwowara. Zboże mełł w młynie miejskim, za co płacił gotówką tylko czeladnikom, a młynarzowi nic nie dawa ${ }^{49}$.

${ }^{46}$ Tamże, s. 86: Percipit item Praepositus victimas Paschales seu Confessionalia a quovis catholico grossos tres. Famuli autem et famulae in servitiis existentes solvunt iuxta antiquam consuetudinem grossos sex.

${ }^{47}$ ADCh, sygn. G-61, s. 267 i 273.

${ }^{48}$ ADCh, sygn. G-60, s. 84.

${ }^{49}$ Tamże, s. 85. 
Na przedmieściu Skarszew, za bramą miejską, znajdowało się 20 domów (viginti) dawnych mansjonarzy, które stanowiły majątek parafii. Oddał je więc w dzierżawę, na następujących warunkach: każdy najemca płacił 3 floreny rocznie i musiał odpracować w czasie żniw 3 dni przy koszeniu zboża lub siana i 3 dni przy ich zwożeniu. Natomiast komornicy w nich przebywający musieli odpracować po jednym dniu. Wszyscy żywili się na koszt własny w czasie pracy. Ci, którzy mieli konie lub woły byli zobowiązani wywozić nawóz przez 2 dni na pola, a którzy ich nie mieli, winni nakładać gnój na wozy. Nadto musieli raz na rok dowieźć jeden wóz drewna i siana do plebanii. Do tego osiedla Wybicki dobudował jeden dom o dwu mieszkaniach, z wynajmu których lokatorzy płacili taki sam czynsz i świadczyli podobne usługi. Razem więc pobierał z nich czynsz w wysokości 66 florenów rocznie i korzystał z ich pracy przez przynajmniej 132 dniów$\mathrm{ki}^{50}$. Z tego tytułu dochód prepozytów powiększył się o 6 florenów i 12 dniówek pracy.

W relacji znajdujemy opis powołania nowej fundacji i wniesienia w Skarszewach szpital-przytułka. Stary zapewne spłonął w czasie pożaru miasta i kościoła w 1712 roku $^{51}$. Starania w tej sprawie podjął wspominany wcześniej ks. J. Jugowski, archidiakon pomorski i prepozyt skarszewski w latach 1693-1712, który przeznaczył na ten cel 600 florenów. Dzieła nie wykonał, ponieważ „zaskoczyła go śmierć”. Ks. F. J. Wybickiemu udało się nakłonić Różę Lewińską i jej syna Joachima do ofiarowania na ten cel 1000 florenów. Dnia 1 października 1756 roku podpisali oni umowę wstępną, a kwotę tę zapisał drugi syn Jan, dziedzic dóbr Bączka, 25 czerwca 1758 roku w sądzie ziemskim w Skarszewach. Dlatego prepozyt w 1758 roku wzniósł przytułek za 786 florenów, składający się z 4 mieszkań i pokrył go dachówką ${ }^{52}$. W 1766 roku w czasie wizytacji ks. Bartłomieja Franciszka Ksawerego Trochowskiego przebywało w nim 8 ubogich $^{53}$.

Oprócz tego uzyskał darowiznę 150 florenów od Wojciecha Damrata, właściciela pewnej gospody. Sam dodał jeszcze 1000 florenów i ostatecznie ulokował w dobrach Lewińskich legat w kwocie 2000 florenów na roczny procent, który przeznaczył na utrzymanie ubogich parafian skarszewskich. Umowę z Janem Lewińskim podpisano 28 lipca w sądzie ziemskim w Skarszewach ${ }^{54}$. Niestety, Wybicki nie podał, na jaki procent ułożył się ze szlachcicem, można jednak przypuszczać, że było to 5-6\%, co dawało 100-120 florenów rocznie. Wynika z tego, że na wzniesienie przytułku uzyskał 1650 florenów i sam dodał 1000 florenów. Z tej kwoty (2650 florenów) wydał 786 florenów na budowę, czyli dołożył jeszcze 136 florenów, by móc ustanowić legat w kwocie 2000 florenów.

Warto podkreślić, że Kościół katolicki w Polsce po niepokojach związanych z falą reformacji, która przyczyniła się do upadku wielu szpitali fundowanych w średniowieczu, realizując postanowienia soboru trydenckiego, podją na nowo zadanie opieki nad potrzebującymi pomocy. Źródłem ich finansowania od XVII

\footnotetext{
${ }^{50}$ Tamże.

${ }^{51}$ ADCh, sygn. G-61, s. 260.

${ }^{52}$ ADCh, sygn. G-60, s. 86.

${ }^{53}$ ADCh, sygn. G-61, s. 275.

${ }^{54} \mathrm{ADCh}$, sygn. G-60, s. 86.
} 
w. stały się legaty i działalność charytatywna bractw miłosierdzia, które powstawały nieco później. Szpitale w archidiakonacie pomorskim powstawały przy większych parafiach. Chociaż nie tak licznie jak w Małoposce, gdzie odsetek parafii ze szpitalikami w latach 1747-1749 wynosił według S. Litaka $61^{55}$, a według P. Gacha $59,5^{56}$. Niemniej jednak duchowieństwo pomorskie wspierało szpitalnictwo odpowiadając na wezwania biskupów $\mathrm{m}$. in. wyrażone na synodach prowincjonalnych i diecezjalnych. Według W. Wójcika w XVII i XVIII w. zwołano ogółem 109 synodów diecezjalnyach i aż $31 \mathrm{z}$ nich w różnym stopniu poruszało problem szpitali ${ }^{57}$. Według B. Kumora w diecezji włocławskiej w połowie XVIII w. na 242 parafie było tylko 41 szpitali $^{58}$, czyli w co piątej parafii istniał przytułek. Jednak w samym dekanacie tczewskim, do którego należała parafia w Skaszewach, były 4 przytułki na 16 kościołów parafialnych i filialnych.

W dekanacie zakład ten był największy i najlepiej uposażony. Przykładowo miasto Tczew miało mały przytułek ${ }^{59}$. W Subkowach dom według relacji z 1750 roku został niedawno odnowiony, mieścił 4 ubogich, ale nie posiadał włsnego uposażenia ${ }^{60}$. W Lubiszewie w małym przytułku mieszkało 5 ubogich żyjących $\mathrm{z}$ samej jałmużny ${ }^{61}$. Porównując inne małe miasta można podać przytułek $\mathrm{w} \mathrm{Pu}-$ cku, który służył 10 ubogim, a jesli chodzi o uposażenie, w Wejherowie w 1766 roku miał 131 florenów rocznego dochodu ${ }^{62}$.

Na zakończenie swojej relacji pisze ks. F. J. Wybicki o próbie odzyskania kościoła i beneficjum we wsi Demblin, gdzie jeszcze za bpa Hieronima Rozrażewskiego stał kościół filialny pw. św. Małgorzaty, mający 4 łany gruntów beneficjalnych. Pozostał tam jedynie cmentarz, na środku którego stoi kropielnica wyrzeźbiona z kamienia, a 2 zachowane dzwony przeniesiono do Skarszew. Aby odzyskać te grunty, uprawiane prawdopodobnie przez wojewodę pomorskiego, wniósł sprawę do sądu assesorskiego, ale prawnicy warszawscy nie chcieli wierzyć dokumentom kościelnym, dlatego proces zawiesił, by dalej szukać dokumentów erekcyjnych parafii i beneficjum.

Podobnie wystapił przeciwko władzom miasta Skarszewy, ponieważ uważał, że w czasie „potopu” szwedzkiego władze przejęły parcele należące do parafii. Były one położone przy drodze prowadzącejzcmentarza dobramygdańskiej, azwią-

${ }^{55}$ S. Litak, Struktura i funkcje parafii w Polsce, w: Kościół w Polsce, red. J. Kłoczowski, t. 2: Wiek XVI-XVII, Kraków 1970, s. 429.

${ }^{56}$ P. Gach, Sieć szpitali w diecezji krakowskiej w połowie XVIII wieku, „Roczniki Humanistyczne", 21 (1973) s. 249-250.

${ }^{57}$ W. Wójcik, Z dziejów kościelnego szpitalnictwa. Archidiakonat sandomierski, „Ateneum Kapłańskie", 41 (1949) z. 51, s. 234.

${ }^{58}$ B. Kumor, Opieka społeczna Kościoła $w$ świetle ustawodawstwa synodalnego $w$ Polsce (do 1795), w: Charitas. Milosierdzie i opieka spoteczna w ideologii, normach postępowania i praktyce społeczności wyznaniowych w Rzeczypospolitej XVI-XVIII wieku, red. U. Augustyniak i A. Karpiński, Warszawa 1999, s. 14

${ }^{59}$ ADCh, sygn. G-56, s. 166.

${ }^{60}$ Tamże, s. 169.

${ }^{61}$ Tamże, s. 172.

${ }^{62}$ Kropidłowski, Dobra materialne, wyposażenie i dochody parafii, s. 71 i 106. 
zane z nimi były pola, łąki i ogrody. Narzekał jednocześnie, iż jest zajęty zbyt wieloma sprawami i nie może zebrać przekonujących dowodów. Dlatego proces zawiesza, ale ,ze względu na to, na tych parcelach obywatelom nie pozwalam budować i moich następców proszę, aby nie pozwalali" ${ }^{\prime 3}$.

Ks. F. J. Wybicki dążąc do odzyskania dochodów wdał się w 6 procesów sądowych. Nie można jednak powiedzieć o nim, że był pieniaczem, ponieważ jeden proces wygrał, dwa w 1758 roku jeszcze się toczyły, a od trzech odstapił narzekając przy tym na trudne czasy i brak życzliwości dla Kościoła. Działalność tak była typowa dla duchowieństwa polskiego w XVIII w. Plebani byli zmuszeni dochodzić swoich należności, szczególnie w dziesięcinach, czy w odsetkach od kapitałów powierzonych, najczęściej szlachcie lub magistratom miejskim ${ }^{64}$.

Na zakończenie wiarygodność swoją poparł przysięga, a relację polecił notariuszowi przepisać do protokołów czynności konsystorza generalnego gdańskiego.

W omawianej relacji ks. F. J. Wybicki nie mówi wszystkiego o swoich dochodach. O pobieranych dziesięcinach więcej możemy się dowiedzieć ze wspomnianej już lustracji starostwa skarszewskiego, przeprowadzonej też w 1758 roku. Ówczesny lustrator odnotował, że na beneficjum składa się 7 włók gruntów. Zapewne tak oszacował grunty główne i różne małe poletka, ogrody i łąki rozrzucone na terenie całego starostwa. Dzieisęcina z miasta powinna wynosić po 77 korców obu zbóż i 15 szotów monety pruskiej, a mieszczanie od posiadłości mieli płacić po 5 szelagów. Według lustratora wieś Demblino obejmująca 40 włók daje od włóki po 0.5 korca pszenicy i owsa, czyli po 20 miar obu zbóż. Wieś Boże Pole, dawniej leżąca na 40 włókach, teraz ma tylko 2 gburów, którzy uprawiają po 2 włóki i składają na dziesięcinę po 1,5 korca pszenicy i owsa, czyli razem po 6 miar. Wieś Szczodrowo obejmowała 36 włók razem z 4 kościelnymi, ale w 1758 roku jej sołtys i 3 gospodarzy, składali się razem po 12 korców pszenicy i owsa. We wsi Nighuta gospodarował sołtys, który uprawiał 4,5 włóki, oraz jeden gospodarz, który uprawiał aż 5 włók. Dziesięcinę składali ,jako i drudzy”, także prawdopodobnie po 1,5 korca od włóki, czyli 13,75 miary obu zbóż ${ }^{65}$.

Podsumowując warto podliczyć dochody ks. F. J. Wybickiego i wymienić osiagnięcia tego prepozyta $\mathrm{w}$ działalności gospodarczej w powierzonej mu parafii św. Michała Archanioła w Skarszewach. Nie prowadził on bezpośredniej działalności gospodarczej, nie uprawiał gruntów ornych, zadawalał się ich dzierżawieniem, bo był zajęty pracami w konsystorzu gdańskim. Kilka razy w roku musiał również odwiedzać swoje kapituły, macierzystą we Włocławku i kolegiacką w Kruszwicy.

Zastanawiają niewielkie kwoty przekazywane do skarbony kościelnej z łanu świątyni parafialnej w porównaniu do czynszów otrzymywanych z najmu gruntów beneficjalnych. Wybicki uprawiał ziemię kościelną i oddawał witrykusom tylko 6 florenów, czyli różnicę zatrzymywał dla siebie. Mogła ona wynosić od 44 do 54 florenów, ponieważ otrzymywał po 50 florenów z łanu należącego do duże-

${ }^{63}$ ADCh, sygn. G-60, s. 87: Nihilominus in istis areis nullas mansiones civibus aedificare permitto, ac meos successores rogo, ut non permittant.

${ }^{64}$ S. Litak, Parafie w Rzeczypospolitej w XVI-XVIII wieku, s. 210.

${ }^{65}$ ADCh, sygn. G-59, s. 132-135. 
go folwarku i aż 60 florenów z małego. Dochód z uprawy jednego łanu ziemi musiał być jednak jeszcze większy, bo i dzierżawcy musieli mieć $\mathrm{z}$ nich jakieś dochody. Minimalne dochody prepozyta F. J. Wybickiego przedstawiam w tabeli 4.

Tabela 4. Najważniejsze dochody roczne ks. F. J. Wybickiego z parafii w 1758 roku

\begin{tabular}{|l|c|c|}
\hline \multicolumn{1}{|c|}{ Źródło dochodów } & Dochody w gotówce & Dochody w naturze i robociźnie \\
\hline Duży folwark beneficjalny & 300 florenów & 6 korców owsa \\
\hline Mały folwark beneficjalny & 60 florenów & 6 korców owsa \\
\hline Dziesięcina & - & $\begin{array}{c}\text { po 141,75 lub } 169,5 \text { korców } \\
\text { pszenicy i owsa }\end{array}$ \\
\hline Iura stolae & 270 florenów i 36 groszy & $\begin{array}{c}43 \text { korce pszenicy i } 40 \text { korców } \\
\text { owsa }\end{array}$ \\
\hline Za chrzty, śluby i pogrzeby & $330-430$ florenów & - \\
\hline Kolęda i na Wielkanoc & około 2000 florenów & - \\
\hline $\begin{array}{l}\text { Dzierżawa uprawnień } \\
\text { karczmarzowi }\end{array}$ & 40 florenów & $\begin{array}{c}132 \text { dniówki pracy w dobrach } \\
\text { prepozyta }\end{array}$ \\
\hline Czynsz z domków mansjonarzy & 66 florenów & $\begin{array}{c}184,75 \text { lub 212,75 korca pszenicy, } \\
193,5 \text { lub 221,5 korca owsa oraz } \\
132 \text { dniówki }\end{array}$ \\
\hline Razem & $2966-3066$ florenów & \begin{tabular}{c}
- \\
\hline
\end{tabular}
\end{tabular}

Na zakończenie można próbować porównać dochody prepozyta skarszewskiego z dochodami innych duchownych zajmujących stanowiska na Pomorzu i innych częściach Polski. Dane te należy traktować jako szacunkowe, ponieważ nie zawsze jest wiadome, jaką moneta, dobrą czy zepsuta, według jakiego kursu (urzędowego czy rynkowego) i według jakiej stopy menniczej płacono oraz który korzec miary stosowano (gdański czy warszawski) ${ }^{66}$. Mimo to można porównać pewne dochody prepozyta szkarszewskiego z 1758 roku, puckiego ${ }^{67}$ i z Lalków ${ }^{68}$ z 1766 roku oraz duchowieństwa diecezji płockiej w 1776 roku $^{69}$, a także archidiakonatu sandomierskiego w latach 1776-1782 ${ }^{70}$.

${ }^{66}$ Por. T. Furtak, Ceny w Gdańsku w latach 1701-1815, Lwów 1935, s. 45-49: mówi o zmieniającej się wartości florena, czyli złotego, a s. 37-39 o różnicach w objętości korca warszawskiego, gdańskiego i innych. Podobnie o monetach polskich mówi J. A. Szwagrzyk, Pieniq̨z na ziemiach polskich $X$-XX w., Wrocław 1990, s. 138-148.

${ }^{67}$ Kropidłowski, Dobra materialne, wyposażenie $i$ dochody parafi, duchowieństwa i sluzby kościelnej dekanatu puckiego, s. 221.

${ }^{68}$ A. Przywuska, Kociewska gmina Smętowo Graniczne. Dziej do roku 2005, Starogard Gdański 2008, s. 368.

${ }^{69}$ D. Główka, Gospodarka w dobrach plebańskich na Mazowszu w XVI-XVIII wieku, Warszawa 1991, s. $81 \mathrm{n}$.

${ }^{70} \mathrm{~W}$. Kowalski, Uposażenie parafii archidiakonatu sandomierskiego $w$ XV-XVIII wieku, Kielce 1998, s. $91 \mathrm{n}$. 
Tabela 5. Dochody z wybranych parafii w II połowie XVIII w.

\begin{tabular}{|l|c|c|c|c|}
\hline \multicolumn{1}{|c|}{ Parafia } & Dochód & Dochód minimalny & Dochód średni & $\begin{array}{c}\text { Dochód } \\
\text { maksymalny }\end{array}$ \\
\hline Skarszewy & $\begin{array}{c}\text { około 3000 } \\
\text { florenów i po 200 } \\
\text { korców pszenicy } \\
\text { i owsa }\end{array}$ & - & - & - \\
\hline Puck & $\begin{array}{c}\text { około 1000 } \\
\text { florenów }\end{array}$ & - & - & - \\
\hline Lalkowy & 506 florenów & - & - & - \\
\hline $\begin{array}{l}\text { Parafie diecezji } \\
\text { płockiej }\end{array}$ & - & - & 813 złotych & 2803 złote \\
\hline $\begin{array}{l}\text { Parafie } \\
\text { archidiakonatu } \\
\text { sandomierskiego }\end{array}$ & - & 130 złotych & groszy & \\
\hline
\end{tabular}

Jak już wcześniej zaznaczono, wartość porównania zależy od wiedzy o wartości pieniądza, położenia geograficznego i z tym związanych cen płodów rolnych, które zależnie od pory roku i urodzajów zmieniały się gwałtownie. Mimo to można uznać parafię w Skarzewach za jedną z bardziej dochodowych, nie tylko na Pomorzu, ale również w Polsce, co łączyło się z częstym powoływaniem jej prepozytów na archidiakonów pomorskich i surogatów oficjałów gdańskich.

\section{BUSINESS ACTIVITIES OF PRIEST \\ FRANCISZEK JÓZEF WYBICKI (1709-1765)}

\section{Summary}

Priest Franciszek Józef Wybicki came from a moderately rich noble family, who rendered great service to the country. Judging from the numerous posts he served at the request of the bishops of Włocławek, he was an educated theologian and lawyer. Apart from managing the parish of the Archangel Michael in Skarszewy (1736-1765), he was a surrogate to several general officials in Gdańsk since 1743; in 1747 he was first mentioned as one of the canons in the Włocławek chapter. Since 1758 he was the chancellor of the Kruszwice chapter and the archdeacon of the Pomorian District since 1764. His business activity was limited to the parish in Skarszewy, situated in the vicinity of Gdansk. First of all, he rebuilt the parish church, which had been consecrated in 1750, where he founded two altars: the main altar, devoted to the Archangel Michael and the one devoted to St Mary. In addition, he built a poor-house for 8 people and furnished it generously. The farm buildings were also restored. He tried to regain the sums due to the provosts of Skarszewy, suing the debtors in six trials; he won one case, two others were still in court when he died and, in view of the fact that he lacked sufficient evidence to win, he renounced the remaining ones.

Priest F.J. Wybicki did not do any business himself; he was content with rebuilding and leasing two home farms, a large and a small one; he also regenerated the parish forest and renounced the taproom rights. He collected tithes, offerings on account of iura stolae or Christmas visits, Easter confessions or donations for celebrating masses. The total parish revenues came up to 3 thousand florins and about 200 bushels of wheat and oats. The tenants were obliged to work 132 days a year for him. Owing to his efforts, the revenues rose by 50\%, the parish remaining one of the most profitable in $18^{\text {th }}$ century Poland. It should be noted that he resigned the offerings of the guild of bakers, whose request to do so was based on their difficult financial situation. 